\title{
Analisis Perubahan Sosial Budaya Masyarakat Desa Cihideung sebagai Desa Wisata
}

\author{
Hanifah Gunawan', Karim Suryadi², Elly Malihah ${ }^{3}$ \\ 'SMA Negeri 2 Cianjur \\ ${ }^{2}$ Dosen Program Studi Pendidikan Sosiologi \\ ${ }^{3}$ Dosen Program Studi Pendidikan Sosiologi
}

\begin{abstract}
ABSTRAK
Penelitian ini dilakukan di Desa Cihideung yang mengalami perubahan sosial budaya dari desa yang didominasi oleh pertanian sawah dan sayuran menjadi desa wisata yang didominasi oleh berbagai macam pembangunan objek pariwisata beserta sarana pendukung lainnya yang dimiliki oleh para investor. Metode penelitian yang digunakan adalah metode penelitian kualitatif. Perubahan sosial budaya yang terjadi antara lain: 1) Berkurangnya interaksi sosial; 2) Berkurangnya solidaritas sosial; 3) Proses sosialisasi dipengaruhi oleh unsur dari luar masyarakat Desa Cihideung; 4) Berkurangnya pengawasan sosial serta kepedulian; 4) Menghilangnya adat istiadat; 5) Meningkatnya eksistensi kesenian tradisional; 6) Mata pencaharian yang menjadi heterogen; 7) Terjadinya mobilitas sosial.
\end{abstract}

Kata kunci : Perubahan Sosial Budaya, Masyarakat, Desa Wisata.

\section{PENDAHULUAN}

Perubahan yang terjadi dalam kehidupan masyarakat meliputi berbagai macam aspek yaitu aspek sosial, budaya, ekonomi, teknologi, maupun ilmu pengetahuan. Begitu halnya di Desa Cihideung kecamatan Parompong kabupaten Bandung Barat terjadi perubahan sosial budaya setelah adaya pembangunan berbagai macam objek pariwisata mulai dari wisata alam, wisata haritage dan wisata buatan seperti permainan, wisata kuliner, maupun penginapan serta butik.

Alasan utama dilakukan penelitian mengenai perubahan sosial budaya masyarakat Desa Cihideung adalah agar setiap pembangunan yang dilaksanakan harap memperhatikan kondisi sosial budaya masyarakat setempat karena dikhawatirkan masyarakat asli akan tersisihkan bahkan sampai menghilang apabila pembangunan tersebut tidak diimbangi dengan pelestarian terhadap 
kebudayaan dan kondisi sosial masyarakat Desa Cihideung.

\section{KONDISI MASYARAKAT DESA CIHIDEUNG SEBELUM MENGALAMI PERUBAHAN DARI KAWASAN PERTANIAN MENJADI DESA WISATA}

Kondisi masyarakat Desa Cihideung sebelum mengalami perubahan dapat diidentifikasi melalui hal-hal berikut ini :
A. Pemanfaatan
lahan didominasi oleh masyarakat Desa Cihideung dalam bidang pertanian

B. Rendahnya jumlah penduduk (9038 jiwa) sehingga tidak terjadi kepadatan penduduk

C. Mayoritas mata pencaharian sebagai petani (sebesar 87\%)

D. Rendahnya tingkat pendidikan (kualitas dan kuantitas pendidikan di Desa Cihideung pun kurang memadai)

E. Interaksi sosial yang kuat (gotong royong, kerja sama, musyawarah, saling sapa, sopan santun)

F. Proses sosialisasi unsurunsur masyarakat pedesaan

G. Memegang teguh normanorma sosial (norma agama, norma kesopanan)

H. Sikap hidup yang sederhana

I. Rendahnya mobilitas sosial baik vertikal karena minimnya kualitas sumber daya manusia dan horizontal karena

J. Teknologi tepat guna dengan cara memanfaatkan sumber daya lingkungan Desa Cihideung

K. Sistem pemerintahan yang belum tersosialisasikan dengan baik

L. Rendahnya ukuran komunitas karena minimnya kualitas sumber daya manusia.

M. Kesenian tradisional yang masih kental dan dilakukan atas dasar keikhasan.

$\mathrm{N}$. Adat istiadat yang masih kental yaitu adat memberikan sesaji kepada mata air sebelum melakukan kegiatan bertani.

\section{PERUBAHAN SOSIAL BUDAYA YANG TERJADI PADA MASYARAKAT DESA CIHIDEUNG SEBAGAI DESA WISATA.}

Pada awalnya masyarakat Desa Cihideung merupakan desa yang mayoritas masyarakatnya bekerja sebagai petani palawija maupun petani sawah, namun pada saat terjadinya pembebasan lahan masyarakat Desa Cihideung mulai berubah profesi menjadi petani bunga potong maupun bibit bunga. Mulai pada saat itulah awal Desa Cihideung dinobatkan sebagai desa agrowisata.

Pembangunan berbagai macam objek pariwisata serta sarana pendukungnya menyebabkan terjadinya perubahan sosial budaya pada masyarakat Desa Cihideung. 
Perubahan tersebut dapat diidentifikasi melalui beberapa hal diantaranya yaitu :

A. Berkurangnya lahan pertanian karena banyak dibangun objek pariwisata

B. Meningkatnya jumlah penduduk karena banyaknya pendatang

C. Mata pencaharian menjadi heterogen karena mulai banyak lapangan pekerjaan non pertanian.

D. Meningkatnya tingkat pendidikan karena tersedianya kualitas dan kuantitas Sekolah di Desa Cihideung serta para orang tua sudah menyekolahkan anaknya untuk bisa mendapatkan pekerjaan.

E. Berkembangnya teknologi modern yang membantu kegiatan masyarakat Desa Cihideung salah satunya adalah telepon genggam, laptop, komputer, warnet dan jaringan internet

F. Berkurangnya interaksi sosial.

G. Memudarnya solidaritas sosial karena adanya pendatang serta wisatawan

H. Meningkatkan eksistensi kesenian tradisional karena didukung oleh pemerintah dan objek pariwisata.

I. Meningatnya Tingkat Keagamaan karena adanya pendatang yang menyebarkan syiar-syiar agama Islam
J. Hilangnya adat istiadat karena tertutupnya mata air yang ada di Desa Cihideung karena pembangunan.

K. Lembaga Kemasyarakatan mulai berkembang dikarenakan meningkatnya jumlah penduduk, meningkatnya pemahaman akan pendidikan sehingga sumber daya manusia yang berkualitas serta bantuan dari objek pariwisata.

L. Sistem Pemerintahan berubah mengikuti perubahan yang dilakukan oleh pemerintah pusat.

DAMPAK YANG DITIMBULKAN DARI ADANYA PERUBAHAN SOSIAL BUDAYA MASYARAKAT DESA CIHIDEUNG SETELAH MENJADI DESA WISATA.

A. Dampak positif

1. Membuat Desa Cihideung terkenal hingga ke mancanegara.

2. Menyediakan lapanga pekerjaan.

3. Memberi bantuan sosial.

4. Meningkatkan eksistensi kesenian tradisional.

5. Meningkatnya taraf hidup masyarakat Desa Cihideung karena adanya pendidikan dan teknologi

6. Tersedianya fasilitas-fasilitas umum salah satunya adalah jalan raya.

B. Dampak negatif

1. Terjadi kepadatan penduduk 
2. Hilangnya sifat-sifat masyarakat pedesaan

3. Pencemaran lingkungan

4. Rendahnya pengawasan sosial

5. Kemacetan

6. Meningkatnya kriminalitas

TANGGAPAN MASYARAKAT DESA CIHIDEUNG TERHADAP PERUBAHAN SOSIAL BUDAYA YANG TERJADI SETELAH MENJADI DESA WISATA

Masyarakat Desa Cihideung mengungkapkan bahwa setiap pembangunan yang terdapat di Desa Cihideung harus banyak memberikan dampak yang positif dan mengurangi dampak-dampak yang negatif sehingga dapat terjadi suatu hubungan yang saling menguntungkan.

Tanggapan tidak setuju yang dikeluarkan oleh bapak Asep sebagai sekretaris desa. Bapak asep tidak setuju mengenai pembangunan yang tidak mendukung terhadap agrowisata Desa Cihideung karena akan membuat masyarakat Desa Cihideung kehilangan identitas sebagai desa Agrowisata. Hal tersebut didukung oleh kepala Desa Cihideung karena beliau tidak mendukung apabila pembangunan tersebut dalam bidang perumahan yang tidak bisa menyerap tenaga kerja yang banyak.

Sebaliknya masyarakat Desa Cihideung cenderung setuju mengenai adanya pembangunan tersebut karena membuat lapangan pekerjaan dan meminimalisir pengangguran bagi usia produktif yang sudah tidak mempunyai lahan dan kemampuan untuk bekerja sebagai petani.

\section{KONDISI MASYARAKAT DESA CIHIDEUNG SEBELUM MENGALAMI PERUBAHAN DARI KAWASAN PERTANIAN MENJADI DESA WISATA}

Kondisi masyarakat Desa Cihideung dapat diidentifikasi melalui hakikat dan sifat masyarakat pedesaan sebelum adanya berbagai macam pembangunan objek pariwisata maupun pendukungnya pada tahun 1999. Hakikat serta sifat masyarakat pedesaan terlihat pada bentuk-bentuk kelompok sosial yang dimiliki masyarakat pedasaan yaitu kelompok paguyuban atau gemainschaft.

$$
\text { Masyarakat }
$$

Desa

Cihideung saling mengenal satu sama lain, mereka saling mengenal hampir satu desa karena mereka pun dapat dikategorikan sebagai keluarga besar sehingga dalam satu desa masih ada ikatan darah yang terjalin.

\section{PROSES PERUBAHAN SOSIAL BUDAYA YANG TERJADI PADA MASYARAKAT DESA}




\section{CIHIDEUNG SETELAH MENJADI DESA WISATA}

Proses perubahan sosial budaya yang terjadi pada masyarakat Desa Cihideung melalui tiga tahap, sebagaimana Soekanto (2008, hlm. 288-291) yaitu:

1) Penyesuaian masyarakat terhadap perubahan; 2) Saluran-saluran perubahan sosial dan Kebudayaan; 3) Disorganisasi dan Persepsi masyarakat Desa Cihideung terhadap wisatawan.

$$
\text { Masyarakat Desa }
$$

Cihideung sebagai desa wisata yang banyak dikunjungi oleh wisatawan yang berasal dari berbagai daerah sehingga membuat berbagai persepsi yang dimiliki oleh masyarakat Desa Cihideung mengenai wisatawan. Hal ini menggambarkan perubahan sikap masyarakat Desa Cihideung terhadap wisatawan secara linier. Sikap yang mula-mula positif berubah menjadi semakin negatif seiring dengan pertambahan jumlah wisatawan. Tahapan-tahapan sikap masyarakat Desa Cihideung terhadap wisatawan mulai dari euphoria, apathy, annoyance dan antagonism adalah sebagai berikut:

1. Euphoria. Pada tahap pertama, kedatangan wisatawan diterima dengan baik oleh masyarakat Desa Cihideung mereka sangat senang bisa berinteraksi dengan wisatawan yang berasal dari luar kota yang mamiliki taraf hidup yang lebih tinggi, dengan sejuta harapan bahwa akan meningkatkan kesejahteraan mereka.

2. Apathy. Pada tahap kedua, masyarakat Desa Cihideung menerima wisatawan sebagai sesuatu yang lumrah karena sudah terbiasa, dan hubungan antara masyarakat Desa Cihideung dengan wisatawan didominasi oleh hubungan komersial dalam hal menjual bibit bunga dan membeli bibit bunga. Sehingga didukung oleh pemerintah dalam hal komersialisasi tersebut dan dinobatkanlah Desa Cihideung menjadi desa wisata.

3. Annoyance. Pada tahap ketiga, titik kejenuhan sudah hampir dirasakan oleh masyarakat Desa Cihideung, dan mereka mulai merasa terganggu dengan kehadiran wisatawan. Karena mulai merasakan dampak negatifnya yaitu kemacetan, pengaruh gaya hidup yang negatif, kerusakan lingkungan dan kebisingan.

4. Antagonism. Pada tahap keempat, masyarakat Desa Cihideung secara terbuka sudah menunjukkan 
ketidaksenangannya dan melihat wisatawan sebagai sumber masalah. Ketidaksenangan tersebut muncul akibat banyaknya dampak negatif yang dihasilkan oleh wisatawan sehingga menyebabkan terjadinya demonstrasi yang dilakukan oleh sebagian masyarakat

Desa

Cihideung.

\section{ANALISIS PROSES PERUBAHAN SOSIAL BUDAYA YANG TERJADI PADA MASYARAKAT DESA CIHIDEUNG MENGGUNAKAN TEORI CULTURAL LAG WILLIAM F OGBURN}

Menurut William F. Ogburn (dalam Lauer, 1993, hlm. 220) perubahan sosial mencakup unsur-unsur kebudayaan baik yang bersifat materiil maupun yang immaterial dengan menekankan pengaruh yang besar dari unsur-unsur kebudayaan yang materiil terhadap unsur-unsur immaterial.

Kondisi ketinggalan budaya (cultural lag) terjadi pada masyarakat Desa Cihideung dimana adanya berbagai macam pembagungan objek pariwisata beserta sarana pendukung yang lainnya tidak bisa dimanfaatkan dengan baik oleh masyarakat Desa Cihideung, melainkan menjadikan masyarakat Desa Cihideung meninggalkan kebudayaan lamanya demi kebudayaan baru. Ketertinggalan budaya atau cultural lag yang dialami oleh Desa Cihideung setelah menjadi desa wisata dapat diidentifikasi sebagai berikut:

1. Masyarakat Desa Cihideung kalah bersaing untuk mengembangkan Desa Cihideung menjadi desa wisata.

2. Masyarakat Desa Cihideung kalah bersaing dengan para pendatang.

3. Adanya pelanggaran terhadap aturan.

4. Masyarakat Desa Cihideung menjadi konsumtif.

FAKTOR

PENYEBAB PERUBAHAN SOSIAL BUDAYA PADA MASYARAKAT DESA CIHIDEUNG

Perubahan sosial budaya yang terjadi pada masyarakat Desa Cihideung tentunya memiliki faktor penyebab terjadinya hal tersebut.

1) Faktor dari dalam Masyarakat Desa Cihideung:

a. Sikap masyarakat Desa Cihideung yang menerima perubahan dengan mudah serta mudah pula terjadinya proses imitasi.

b. Kebutuhan masyarakat Desa Cihideung dalam hal pemenuhan kebutuhan ekonomi yang meningkat.

2) Faktor dari luar masyarakat Desa Cihideung: 
a. Pengaruh kebudayaan masyarakat lain yang berasal dari kebudayaan masyarakat perkotaan oleh para wisatawan ataupun dari kebudayaan masyarakat pendatang yang menetap di Desa Cihideung dan melakukan kontak dengan masyarakat Desa Cihideung.

b. Sistem pendidikan formal yang baru dan dimiliki oleh masyarkat Desa Cihideung berupa bertambahnya kuantitas dan kualitas sekolah mulai dari tingkat Play Group, Taman kanakkanak dan Sekolah Dasar. Serta meningkatnya pemahaman akan pentingnya pendidikan.

c. Sikap menghargai hasil karya orang lain yang diidentifikasi melalui sikap masyarakat Desa Cihideung yang ikut berpartisipasi dalam kegiatan yang diselenggarakan oleh berbagai objek pariwisata beserta sarana pendukung yang lainnya.

d. Toleransi terhadap penyimpangan salah satunya adalah sikap permisif masyarakat Desa Cihideung terhadap kegiatan negatif yang diselenggarakan oleh objek pariwisata serta sarana pendukung yang lainnya.
Kegiatan tersebut sudah dengan jelas melanggar norma-norma serta kebiasaan masyarakat Desa Cihideung.

\section{BENTUK PERUBAHAN SOSIAL BUDAYA YANG TERJADI PADA MASYARAKAT DESA CIHIDEUNG SETELAH MENJADI DESA WISATA.}

Perubahan sosial budaya yang terjadi pada masyarakat Desa Cihideung dikategorikan sebagai perubahan sosial budaya yang cepat. Berbagai macam pembangunan baik fasilitas umum maupun objek pariwisata dan sarana pendukung lainnya yang dimiliki oleh para investor, serta teknologi berkembang di Desa Cihideung dalam kurun waktu 15 tahun. Perubahan sosial yang cepat pada masyarakat Desa Cihideung menyebabkan disorganisasi karena berada dalam proses penyesuaian hal tersebut diidentifikasi melalui sikap konsumtif masyarakat Desa Cihideung.

\section{DAMPAK YANG DITIMBULKAN DARI ADANYA PERUBAHAN SOSIAL BUDAYA \\ MASYARAKAT DESA CIHIDEUNG SETELAH \\ MENJADI DESA WISATA.}

Perubahan sosial budaya banyak diakibatkan oleh modernisasi dan globalisasi yang menyabar keseluruh penjuru dunia. Perubahan sosial budaya tersebut tentunya akan 
menimbulkan dampak yang

dirasakan oleh masyarakat yang mengalami

perubahan,

sebagaimana

dalam

Murdiyatmoko (2008, hlm. 19) Modernisasi memiliki dua dampak, yaitu : 1) Dampak positif antara lain terciptanya masyarakat yang dinamis untuk mencapai keadaan yang maju, adil dan sejahtera; 2) Dampak negatif antara lain munculnya berbagai masalah sosial contohnya adalah kriminalitas, kesenjangan sosial, konflik sosial. Pada masyarakat Desa Cihideung yang mengalami proses perubahan sosial budaya juga menimbulkan dampak positif maupun dampak negatif yaitu:

A. Dampak positif

1) Membuat

Desa

Cihideung terkenal hingga ke mancanegara

2) Menyediakan lapangan pekerjaan

3) Memberi bantuan sosial

4) Meningkatkan eksistensi kesenian tradisional

5) Meningkatnya taraf hidup masyarakat

Desa Cihideung karena adanya pendidikan dan teknologi

6) Tersedianya fasilitasfasilitas umum salah satunya adalah jalan raya

B. Dampak negatif
1) Terjadi kepadatan penduduk

2) Hiangnya sifat-sifat masyarakat pedesaan

3) Pencemaran lingkungan

4) Rendahnya pengawasan sosial

5) Kemacetan

6) Meningkatnya kriminalitas.

TANGGAPAN MASYARAKAT DESA CIHIDEUNG TERHADAP PERUBAHAN SOSIAL BUDAYA YANG TERJADI SETELAH MENJADI DESA WISATA.

\begin{tabular}{lr}
\multicolumn{2}{c}{ Keberadaan berbagai } \\
macam pembangunan objek \\
pariwisata beserta sarana \\
pendukung lainnya yang \\
mengakibatkkan perubahan
\end{tabular} sosial budaya pada masyarakat Desa Cihideung menghasilkan berbagai tanggapan, dan tanggapan tersebut nantinya sebagai masukan bagi para pelaku objek pariwisata maupun sarana pendukung lainnya agar selalu melakukan evaluasi. Sebagaimana menurut Cooley (dalam Setiadi, dkk, 2007, hlm. 68) ...diri seseorang memantau apa yang dirasakannya sebagai tangapan masyarakat terhadapnya.

Tanggapan dari masyarakat Desa Cihideung terhadap pembangunan tersebut antara lain adalah tanggapan setuju dan tidak setuju. Masyarakat Desa Cihideung yang memberikan tanggapan setuju 
karena pembangunan berbagai macam objek pariwisata dan sarana pendukungnya memberikan banyak manfaat positif bagi masyarakat Desa Cihideung, sedangkan tanggapan tidak setuju karena masyarakat Desa Cihideung merasakan lebih banyak dampak negatifnya dibandingkan dengan dampak positif.

\section{PENUTUP}

Kondisi masyarakat Desa Cihideung sebelum mengalami perubahan dari kawasan pertanian menjadi desa wisata dapat diidentifikasi pada tahun 1999. Mayoritas mata pencaharian masyarakat Desa Cihideung cenderung homogen dinominasi oleh petani dengan jumlah $87 \%$, sebagai buruh tani sebanyak $10 \%$, pedagang sebanyak $5 \%$ dan pekerja bangunan sebanyak $3 \%$, Rendahnya tingkat pendidikan yang disebabkan oleh rendahnya pemahaman masyarakat Desa Cihideung akan pentingnya, interaksi sosial yang kuat yang dicerminkan dalam sikap gotong royong, saling membantu, sikap sopan santun, sikap musyawarah, proses sosialisasi yang terjadi pada masyarakat

\section{DAFTAR PUSTAKA}

Lauer, Robert. H. 1993. Perspektif tentang Perubahan Sosial. Jakarta: PT. Rhineka Cipta.

Malihah, Elly \& Kolip, Usman. (2011). Pengantar Antropologi. Bandung: CV. Maulana Media Grafika

Murdiyatmoko, Janu. (2008). Sosiologi Memehami dan Mengkaji Masyarakat. Bandung : Grafindo Media Pratama

Soekanto, Soerjono. (1991). Sosiologi Suatu Pengantar. Jakarta : Raja Grafinda Persada. 